\title{
A Comparison of Approaches to the Teaching and Learning of Science in Chinese and Australian Elementary Classrooms: Cultural and Socioeconomic Complexities
}

\author{
Ying Tao, Mary Oliver, and Grady Venville \\ Graduate School of Education \\ The University of Western Australia
}

\begin{abstract}
Set in the context of today's globalized approaches to curriculum reform, the purpose of this study was to compare the teaching and learning of science in Chinese and Australian Grade 6 classrooms. A conceptual framework based on notions of culture and socioeconomic status informed the research design. Case study participants were three teachers of science and 140 students from three elementary schools of high, medium, and low socioeconomic status in Hunan Province, China; and three teachers and 105 students from paired schools in Western Australia. The formal curriculum, the curriculum-in-action, and the experiential curriculum in all case studies in each country were examined. Both qualitative and quantitative data were collected with student questionnaires, lesson observations, teacher interviews, a school tour, and document collection. Findings indicated that participating Chinese students reported a greater proportion of their science lessons involved activities such as reading textbooks and memorizing facts, activities that are consistent with Confucian educational culture. In Australia, where there has been a longer historical influence from social-constructivist theorists such as Bruner and Vygotsky, students reported their lessons involved a greater proportion of activities such as designing and doing science experiments, and working in small groups. The findings also indicated that in both countries, socioeconomic status was an important factor impacting the implementation of the science curriculum with students in higher socioeconomic status schools participating more frequently in classroom activities consistent with reform curriculum documents. This phenomenon was more apparent in China possibly due to the Confucian educational tradition supporting culturally viable alternative approaches to the teaching and learning of science.
\end{abstract}

Keywords: elementary science, China, Australia, reform, comparative study,

Tao, Y., Oliver, M., \& Venville, G. (2013) A comparison of approaches to the teaching of science in Chinese and Australian elementary classrooms: Cultural and socioeconomic complexities. Journal of Research in Science Teaching. 50(1) 33-61

Doi: $10.1002 /$ tea.21064 
Page 2 of 34 


\section{Introduction}

Recent science curriculum reforms in developing nations have been driven by the need to improve standards of living and economic development and have resulted in the logical adoption of what is perceived to have been successful in developed nations (Chiu \& Duit, 2011; Coll \& Taylor, 2012; Guo, 2007). The most common attributes of these new curricula are their constructivist origins, and the inclusion of student-centered, inquiry-based pedagogies (Coll \& Taylor, 2012). Few, however, are rigorously evaluated in the contextualized educational setting. This is an important issue for countries like The People's Republic of China (henceforth referred to as China) that has, over the past decade, adopted approaches to science education that have closer cultural connections and a longer history of implementation in western countries, like Australia (Ding, 2008).

In both China and Australia there is evidence of what has been referred to as a global shift (Adamson, 2012; Chiu \& Duit; Scott, 2008) in the approaches to science curricula, in China at the beginning of the $21^{\text {st }}$ Century and in Australia a little earlier, in the last decade of the $20^{\text {th }}$ Century. Through the development of new curriculum documents, both countries shifted the focus to scientific literacy as the goal of science education, situated social constructive theory as underpinnings, and embraced student-centered and inquiry-oriented pedagogies (Curriculum Corporation, 1994; Ministry of Education [China], 2001; 2010). China and Australia are countries with very different cultural backgrounds based on eastern and western philosophies but we know very little about how global approaches to science curriculum are enacted in different cultures (Coll \& Taylor, 2012). These two countries provide contrasting contexts that allow us to better understand what it is that children in different cultures experience in the classroom during elementary science instruction, and the influence that culture has on the way that 'global' science curricula are delivered (Fensham, 2007).

Comparative, cross national research provides opportunities for collaboration, comparison, and reflection; all of which can lead to improved teaching and learning and improved educational outcomes (Cai \& Lester, 2007). This kind of research is important for both China and Australia as these countries continue to strive to improve the science education for all their students (Australian Curriculum Assessment and Reporting Authority, 2011; Chen, 2004; Wei, 2008a, 2008b; Ministerial Council on Education Employment Training and Youth Affairs, 2008). Moreover, cross national studies have the capacity to elucidate contextual differences and provide contrasting perspectives that might enable researchers to notice important differences or similarities about the educational systems involved (Aldridge, Fraser, \& Huang, 1999; Coll \& Taylor, 2012). This type of research, therefore, casts critical light on what has been referred to as the "transplantation of knowledge" (Kyriakides, 2006, p. 516) from the educational system of one country to another without acknowledging context.

\section{Purpose of the research}

The purpose of the research presented in this paper was to investigate how the elementary science curriculum is enacted in China and Australia and to explore the influence of the different cultural contexts on the enactment of the curriculum. In designing the research questions, we found it useful to conceptualize the curriculum as having three representations: the formal curriculum, that is, "the vision elaborated in a curriculum document" (van den Akker, 1998, p. 421); the curriculum-in-action, defined by van den Akker (1998) as "the actual instructional processes in the classroom" (p. 422), something that also is referred to as the operational or the 
enacted curriculum; and the experiential curriculum, defined as "the actual learning experiences of the students" in contrast with what an observer or the teacher thinks they are doing (van den Akker, 1998, p. 422). These three representations, when examined together, provide a triangulated portrait of how the science curriculum is implemented (Cogan, et al., 2001). The research was structured as six case studies of the teaching and learning practices of six elementary school teachers of science, three in each country. The research questions were:

1. How is the formal science curriculum organized in each Chinese and Australian case study school and classroom?

2. What does the curriculum-in-action look like in each Chinese and Australian case study?

3. What is the experiential curriculum in science for participating Chinese and Australian Grade 6 students?

\section{Conceptual Framework and Literature Review}

The conceptual framework for this research was developed from two aspects of the literature. The first aspect is the notion of 'culture' and how it relates to curriculum and educational practices. The second aspect is the notion of 'socioeconomic status' of schools and its impact on students' education. Previous research in both China and Australia has shown that the socioeconomic status of schools influences the learning outcomes for students (Qian \& Smyth, 2005; Thomson et al., 2011). Further, our own previous research indicated that the socioeconomic status of the schools in which our case studies were located correlated with participating students' conceptual understanding of science (Tao, Oliver, \& Venville, 2012a, 2012b). It was considered important not to ignore this variable when examining curriculum and culture. The following sections expand these two aspects of the conceptual framework.

\section{Culture}

Bruner (1966) considered schooling to both enculture children and promote that culture. Alexander (2000) also alluded to a complex connection between the customs and values of a particular society and life in schools within that society; "a culture does not stop at the school gate" (p. 29). The comparative study described in this paper is based on an understanding that culture is a two-way phenomenon with respect to school and the wider society: a complex potpourri of experiences, beliefs, and values that an individual brings to school as well as those that the individual interacts with at school. Cogan, Wang, and Schmidt (2001) concur that schooling itself is part of a country's culture, which is reflected by the way schooling is organized, the way curriculum is specified and organized, and what students are expected to learn and be able to do. Therefore, "a country's curriculum is itself a cultural artifact" (Cogan, et al., 2001, p. 106). Accordingly, the following section provides an analysis of the curriculum in China and Australia as a cultural artifact of the respective countries.

\section{Culture and approaches to curriculum in China and Australia}

Education in China is profoundly influenced by Confucian philosophy (An, 2004; Li, 2004). The English word 'education' is equivalent to jiao $y u$ in Chinese, which means teaching and cultivating. To be more specific, jiao shu yu ren, means teaching books and cultivating people. Transmitting Confucian morals, imparting knowledge, and resolving doubts are the major responsibilities of teachers. Students pay great respect to teachers and are also attentive to books, 
which are regarded as beneficial and sacred and the study of books, reading and self-reflection are recommended learning strategies (Leng, 2005). Reading, learning, and education are often taken as synonyms in China and reading is regarded as a highly effective means of learning and memorization (OECD, 2011).

While Confucianism is the cultural root of the curriculum in China, the Chinese curriculum has had many influences including Dewey's Pragmatism in the 1920s, Marxist educational ideology in the 1950s, and a national policy of revitalizing China through science and education in the 1990's (Li, 2004). In 2001, the Ministry of Education (MOE) issued a circular entitled the Guidelines for Curriculum Reform of Basic Education. The circular called for an end to the overemphasis on imparting book knowledge and repetitive rote-learning. The circular stressed the importance of student participation, doing practical work, and enhancing students' capacity in communication and teamwork (Ministry of Education [China], 2001).

In contrast with China, Australia's education system largely evolved from the British curriculum and school structures consistent with its colonial past and current Commonwealth status. As in the UK and the USA, curriculum documents in Australia through the 1970s and 1980s were based on behavioral objectives that reinforced didactic forms of teaching where the teachers inculcated knowledge, skills, or affective dispositions into learners by informing them about what they should do and how they should behave (Scott, 2008). The influence of theorists such as Bruner (1966) and the earlier work of Vygotsky (1978) challenged these didactic approaches and influenced curriculum documents and teaching approaches in the west by bringing attention to the social and cultural aspects of teaching and learning (Tytler, 2012). These new perspectives positioned learners as constructing knowledge through contextualized experiences inside and outside the classroom, and through interaction with other people. In 1989, the Australian Education Council published A Statement on Science For Australian Schools (Curriculum Corporation, 1994) that provided a framework for curriculum development for all Australian states and territories. The documents were underpinned by a social constructivist and student-centered approach to learning and teaching (Dawson \& Venville, 2012). This statement initiated movement away from rigid syllabus documents to more flexible curriculum frameworks in each of the Australian states including Western Australia, the state where this research was conducted (Curriculum Council, 1998). The Curriculum Framework for Kindergarten to Year 12 Education in Western Australia (Curriculum Council, 1998) was the official curriculum at the time this research was conducted. In 2012, when this paper was being written, Australia was implementing a national curriculum for the first time.

The current, national elementary science curriculum in China, Science Curriculum Standard (3-6 Grade) for Full-time Compulsory Education, issued by the MOE in 2001 has three content strands, namely World of Living Things, World of Materials, and Earth and Beyond. Enhancing the scientific literacy of all students and helping them to understand the essential nature of science is the core of this science curriculum. Further, the science curriculum is not only designed to meet the needs of individuals, it also is designed to promote social development, and science inquiry (APEC Human Resources Development Working Group, 2006; Division of Primary Education Ministry of Education [China], 2002). In Western Australia, the Curriculum Framework Learning Statement for Science (Curriculum Council, 1998) consists of two key domains: working scientifically (an inquiry domain), and understanding concepts. Within understanding concepts there are four main content outcomes, namely, Earth and Beyond, Energy and Change, Life and Living, and Natural and Processed Materials. Within working scientifically, students are expected to investigate and to communicate their findings. The 
following section explores the empirical literature that describes the science curriculum-in-action (van den Akker, 1998) in China and Australia.

\section{Empirical research on the curriculum-in-action in China and Australia}

"Confucian-heritage" culture classrooms are known for their large class sizes of more than 40 students, highly authoritarian learning climate, expository teaching methods, and examinationoriented learning (Biggs, 1996, p. 46). According to Stigler and Stevenson (1991) there is a common western stereotype of the Asian teacher as an "authoritarian purveyor of information, who expects students to listen and memorize answers and procedures rather than to construct knowledge themselves" (1991, p. 43). Some research has confirmed that, with Confucianism as the main conception of teaching, many science teachers in mainland China and other Asian countries prefer an authoritarian, directed style to their teaching practice, and tend to dominate most of the class time with lectures (Gao, 1998; 1995; Chang \& Mao, 1999). Students are said to be used to being passive and are not accustomed to participating in cooperative learning (Aldridge, et al., 1999; Chang \& Mao, 1999). Teachers explained that the way they teach, for achievement rather than conceptual understanding, is constrained by a crowded curriculum and the importance of examinations (Aldridge, et al., 1999; Cortazzi, 1998). Researchers also have provided more insight into Confucian heritage-based instruction. For example, Cortazzi (1998) revealed teachers' strong expectations of group conformity which was attributed to "collective orientation" (1998, p. 43). He found that the interactive whole-class teaching style had a rapid pace with a variety of activities, lots of active involvement, and both verbal and cognitive participation from students.

Empirical research of science teaching and learning in Chinese classrooms since the implementation of the new curriculum in 2001 is very limited (Zhong, 2006) and it is difficult to know the degree to which the new initiatives have been implemented in schools. However, surveys on the implementation of the science curriculum in Shanxi Province (Hu, Han, \& Liu, 2007) and Hunan Province (Zhou, 2006) revealed that the majority of students in the participating rural schools were taught by teachers without a specialization in science, and were often engaged in rote-learning.

The actual picture of the teaching and learning of science in elementary schools in Australia was found by Goodrum, Hackling, and Rennie's (2001) extensive, national study to be quite different from the ideal one, but reflecting considerable variability. At one end of the spectrum, it was found that science was not taught at all in some elementary schools. At the other end, elementary science was taught in a highly student-centered and activity-based manner, which students tended to enjoy (Goodrum, Hackling, \& Rennie, 2001).

The Trends in International Mathematics and Science Study (TIMSS) video study (Lokan, Hollingsworth, \& Hackling, 2006), a comprehensive study of the eighth grade science teaching in five countries, including Australia, found that about 90 percent of Australian science lessons included practical activities, which were directed or guided by the teacher and undertaken by students working in groups. Some Australian educators have expressed their concern that the actual methods of school science in Australia are too simplistic and that authentic scientific investigations are rarely performed (Nall-Bird, 2004). Science teachers who participated in the TIMSS video study tended to distribute equal time to whole-class instruction and group work. According to Australian teachers' feedback in the (TIMSS) 2007 Report, only four percent of Australian teachers reported that they used textbooks as a primary resource for the teaching of elementary science (Martin, Mullis, \& Foy, 2008). 


\section{Socioeconomic status and educational outcomes in China and Australia}

Little is currently known in western, developed nations about the educational attainment of Chinese students in science due to mainland China's previous lack of participation in international comparative tests such as PISA (Programme for International Student Assessment) and TIMSS (Trends in Mathematics and Science Studies). For the first time Shanghai-China and Hong Kong-China participated in PISA 2009 where these educational jurisdictions performed first and third best in the ranking of 34 participating Organisation for Economic Co-operation and Development (OECD) countries on scientific literacy. Shanghai-China (575 score points) and Hong Kong-China's (549 score points) 15 year-old students achieved, on average, significantly higher than Australian 15 year-old (527 score points) and the OECD average (501 score points) (Thomson et al., 2011). Shanghai-China's performance on China's debut in the PISA 2009 tests stunned educators around the world (Dillon, 2010). It has been acknowledged by officials administering the test that the results from Shanghai are not representative of the whole of China (Dillon, 2010). Shanghai is an industrial powerhouse that is said to attract many of the best students in the country. The outstanding results from Shanghai, however, were said to be as a sign of China's rapid modernization and also an indication of what China could achieve in years to come (Dillon, 2010).

While Shanghai-China performed in an outstanding way in PISA 2009, other research shows substantial disparities between urban and rural areas, and between coastal regions and other regions in school spending in both elementary and lower secondary schools in China (Tsang \& Ding, 2005). Further, the gap between China's urban and rural children's educational attainment has been shown to be the dominant component in educational inequality (Qian \& Smyth, 2005). This research indicates that while Shanghai and Hong Kong schools have been able to achieve remarkable results that top the world in rankings in science achievement, there is a vast population of children in schools in rural regions and in the middle and western provinces of China whose science education may be far from optimal.

Australia also has problems with regard to equity in science education. The findings from PISA 2009 showed statistically significant differences in scientific literacy between 15 year-old Australian students in the highest and lowest quartiles based on socioeconomic background equivalent to about two and a half years of schooling (Thomson et al., 2011). Similarly, there were significant differences in scientific literacy between students attending metropolitan schools, provincial schools, and remote schools (Thomson, et al., 2011). Using data from the Australian 2003 PISA, Perry and McConney (2010a, 2010b) found that increases in the mean socioeconomic status of a school are associated with individual academic achievement, regardless of the socioeconomic status of the student. Moreover, analysis of the TIMSS 2007 data indicated that parental education, used as a proxy for socioeconomic status, was highly positively correlated with student achievement in science in both Grade 4 and Grade 8 and that the gap between students in remote schools and those in other schools in Australia was particularly large (Thomson \& De Bortoli, 2008).

\section{Significance of the research}

This paper presents a first attempt to compare how elementary school science is taught and experienced in Chinese and Australian elementary classrooms. The significance of this research is that it addresses aspects of science teaching and learning that Fensham (2007) claims the large multi-national tests such as PISA and TIMSS fail to do: "the reports of these two projects give 
very little sense of what the students are experiencing day by day with their teachers in the science classrooms, and how this can be improved" (Fensham, 2007, p. 168). This research provides insight into the pedagogical practices in elementary school science lessons in two countries with different cultures and different traditions in education.

This research is significant because it takes into consideration the cultural differences in the ways that the elementary science curriculum is delivered and the variation with regard to socioeconomic status within each of the countries. As the world moves towards a more globalized science curriculum, it is important that we critically examine the adoption of more standardized approaches to the teaching and learning of science in different cultural contexts (Anderson, 2007; Coll \& Taylor, 2012), and the disparities between the achievement of students in schools of different socioeconomic status (Perry \& McConney, 2010a). In-depth case studies of classroom teaching practice are useful ways to gain insight into what is happening for students in their day-to-day learning of science and to explore contexts around disparities in student achievement. This study examines the teaching of science in elementary classrooms across two countries with eastern and western traditions, in the context of the adoption of contemporary approaches to curriculum, and in schools of differing socio-economic status. As indicated previously, the study is unique, but also multilayered. This research provides us with valuable insight into the adoption of global approaches to science curriculum in different countries, and the complexities and interaction of culture and socioeconomic status with these curricula.

\section{Methods}

The research design was a multiple, comparative case study (Yin, 2003) of the teaching and learning practices of six Grade 6 teachers of science, three in China and three in Australia. This study was designed to explore the way the formal curriculum was organized (Research Question 1); the curriculum-in-action, or what the teachers did to teach elementary science (Research Question 2), and, the experiential curriculum, or the students' perceived experiences during science instruction (Research Question 3). The examination of each of these aspects of the curriculum is a form of triangulation of data sources that enhances the rigor of the research (Patton, 2002) and provides a richer understanding of classroom activities from both observer and student perspectives. The last semester of Grade 6 was considered the most appropriate time in elementary school to conduct the research because students in both countries have received a minimum four years of science instruction and were, therefore, likely to understand what science is, know when their teachers were teaching science, and recognize different approaches to teaching.

The research was conducted in Hunan Province, central south China and Western Australia. Hunan is an inner and agricultural province, located at the middle reach of the Yangtze River. It covers an area of 211,800 square kilometers and has a population of about 66 million, of which Han Chinese account for 89.9 percent and minority ethnic groups the remainder. Changsha is the capital city and the province has abundant natural resources including non-ferrous metals and non-metallic minerals (Hunan Provincial Government, 2011). Situated in the southern hemisphere, Western Australia is the largest state in Australia covering a land area of over 2.5 million square kilometers. The population is only 2.3 million, almost 75 percent of whom live in the capital city, Perth. The state has abundant resources in iron ore, nickel, aluminum, gold, and natural gas. Approximately 29.3 percent of the people living in Western Australia were born in 
another country, and 12.4 percent speak a language other than English at home (Australian Bureau of Statistics, 2011). Both Hunan Province and Western Australia have a comprehensive education system compulsory for nine and ten years respectively (The Department of Education of Hunan Province, 2011; Thomson, Ainley, \& Nicholas, 2007).

Six teachers, three from each country and each with a minimum of ten years teaching experience, were selected as the keystone of each case study. A number of steps were taken to facilitate the comparison of the case studies including selecting three pairs of teachers from high, medium, and low socioeconomic status schools, each school from a similar geographic location and a similar sector (Table 1). A total of 140 Chinese students and 105 Australia students participated in the research. The schools in which the case studies were located were represented by the notation: $\mathrm{C} 1(n=46), \mathrm{C} 2(n=44)$, and C3 $(n=50), \mathrm{C} 1$ being the high socioeconomic school and C3 the low socioeconomic school in China. Similarly, the schools in Australia were represented by the notation: A1 $(n=31), \mathrm{A} 2(n=34)$, and A3 $(n=40)$ (Table 1).

Insert Table 1 about here.

The socioeconomic status of the three Australian schools was determined through a metric called Index of Community Socio-Educational Advantage (ICSEA) that is available from the federal government's 'My School' website (http://www.myschool.edu.au). The socioeconomic status of the three Chinese schools was estimated through the principals' reports on a questionnaire about the school's demographic characteristics, resources, and environment. The questionnaire was based on the Chinese version of the TIMSS 2007 school questionnaires (http://www.sec.ntnu.edu.tw/NSC/TIMSS/TIMSS.htm). Previous research conducted in these same schools showed that there were no statistically significant differences in the science understanding of Grade 3 children in the paired schools (Tao, et al., 2012a); however, Grade 6 children in the medium and low socioeconomic schools in Australia were found to have significantly better conceptual understanding of science than their Chinese counterparts (Tao, et al., 2012b). The paired schools also were matched for a number of other important variables. Both $\mathrm{C} 1$ and $\mathrm{A} 1$ are fully government funded and situated next to the campus of a prestigious university in a capital city. Students and teachers in both schools had considerable access to facilities that support education such as museums, municipal libraries, science centers, and cultural and international events. Both $\mathrm{C} 2$ and A2 are government funded with a small financial contribution from the students' parents. The financial contribution from parents results in both schools being well resourced and principals of both schools reported active participation and interest from parents in the students' education. Both low socioeconomic schools, C3 and A3, are fully government funded and located in a semi-rural area approximately 1.5 hours by car from the province/state capital city. Most children attending these schools lived in the immediate locale and their parents generally had working class occupations such as farmers or factory workers. Principals of both schools reported that children generally came from comparatively poor families and the schools experienced associated issues such as difficulty with teacher recruitment and lack of access to resources.

\section{Data collection and analysis}

Three main forms of data collection were used to answer the research questions including 1) a teacher interview, including a school tour and document collection, 2) lesson observation, and 3) a student questionnaire. Each of these methods of data collection is elaborated below. 


\section{Teacher interviews, school tour, and document collection}

To gain insight into how the formal science curriculum was organized (Research Question 1), an interview, that incorporated a school tour and document collection, was conducted with each case study teacher. The interview protocol (Appendix A) was developed to focus on issues indentified by Appleton (2007) for elementary school science and included questions about the teacher's specialization, teaching resources, instruction time, textbook use, and the facilities availability at the school such as a science laboratory and/or science equipment. The interview also included a tour of the school and observation of the science laboratory or classroom and storage facilities for science equipment if they existed in the school. During the interview and school tour with the science teacher, relevant documents including teaching programs were photocopied and returned to the teacher. Interviews were audio recorded and digital photographs were taken of the science facilities in each school. The semi-structured interview took approximately 20 minutes for each teacher (120 minutes in total for all six teachers). The school tour and document collection took an additional 45 minutes to an hour, (approximately 5-6 hours in total for the six schools). The data were analyzed around the issues raised by Appleton (2007) listed above and used to generate a table summarizing information relevant to Research Question 1 about how science is organized in each case study.

\section{Lesson observation}

Lesson observations were conducted in order to collect data about the science curriculum-inaction (Research Question 2). One science lesson in each case study was observed by a researcher from China and a researcher from Australia. One lesson from each case study was considered sufficient as one aspect of the triangulated data used for this study. Each teacher was consulted about an appropriate time for the classroom observation and to ensure the observed lesson reflected their typical approach to the teaching of science in Grade 6. In all cases, the teacher invited the researchers to observe the next science lesson. It was considered important that researchers from both cultures visited all case studies in both countries so that interpretations of the data could be compared and discussed from the different cultural perspectives. This approach enhanced the rigor of the research through a processes termed "analyst triangulation" (Patton, 2002, p. 556). In China, one of the researchers whose mother tongue is Mandarin consecutively interpreted the lesson to the English speaking researcher.

The duration of observation was approximately 45 minutes for each science lesson in China and Australia (250 minutes in total). Field notes and audio recordings were used to collect data using an observation protocol (Appendix B) developed from Walker and Adelman's (1975) guidelines and observation points (pp. 7-19). The use of both field notes and audio recordings is a form of triangulation of sources (Patton, 2002). The field notes and audio recordings were analyzed based on the observation protocol to generate a summary of each lesson outlining the topic of the lesson, the activities observed during the introduction of the lesson, the body of the lesson, and the lesson conclusion. The summaries were developed by one observer and checked and discussed with the second observer. Some minor modifications were made to the summaries as a result of the discussion and reference back to the raw data.

\section{Student questionnaire}

A student questionnaire was administered to all participating 6th graders in all case studies to collect data that reflected the experiential curriculum (Research Question 3). The questionnaire included nine items on students' perceptions of classroom instructional practices related to science teaching, which were selected from the TIMSS 2007 student questionnaires, 

at something like the weather or a plant growing and writing down what I see; 2) watching the teacher do a science experiment; 3) designing a science experiment or investigation; 4) doing a science experiment or investigation; 5) working with other students in a small group on a science experiment or investigation; 6) reading books about science; 7) memorizing science facts; 8) writing or giving an explanation for something I'm studying in science; and, 9) working out science problems on my own. (The complete student questionnaire is presented in Appendix C.) Students responded on a scale of four statements including: 'at least once a week', 'once/twice a month', 'several times a year (rarely)' or 'never'. The TIMSS 2007 Technical Report provides detailed information on the reliability and validity of the questionnaire (http://timssandpirls.bc.edu/TIMSS2007/techreport.html). The student questionnaire also was pilot tested with non-participating Grade 6 students in a different school. A full report of the pilot study is available in Tao (2012).

The students' responses to the questionnaire items were assigned scores of three, two, one, and zero for the most to the least frequent activity and entered into a SPSS (Statistical Package for the Social Sciences) database. Due to the ordinal (ranked) nature of the data, non-parametric approaches to statistical analysis were used (Allen \& Bennett, 2008). The statistical analysis involved two main phases, between country and within country. The between country phase employed a Mann-Whitney U Test to identify any statistical differences between the responses from the participating Grade 6 students from China and Australia (Allen \& Bennett, 2008). The within country phase employed a Kruskal-Wallis One-Way ANOVA to search for statistically significant differences in the responses of students from case studies in schools of different socioeconomic status within China and within Australia. Where statistically significant differences were found, a series of Mann-Whitney U Tests was conducted to ascertain between which of the three case studies in each country the differences were located (Allen \& Bennett, 2008). Follow up analyses were conducted to ascertain effect sizes as suggested by Allen and Bennett (2008, p. 237) to quantify the magnitude of the difference that we found between the two groups. The $z$ statistic from Mann-Whitney U Tests were converted into $r$ and Cohen's (1988) conventions used to describe the effect size ( $r=.1$ small, $r=.3$ medium, $r=.5$ large). The effect sizes give an indication of the practical importance of the findings (Berben, Sereika, Engberg, 2012).

\section{Findings}

The findings are presented in three sections that address the research questions. The first section presents the findings of the organization of the formal curriculum in each case study based on the teacher interview, school tour, and document collection. The second section presents findings about the curriculum-in-action in each case study based on lesson observations. The third section presents the quantitative data on of the experiential curriculum from the student questionnaire.

\section{Organization of the formal curriculum}

An overview of the science teaching context in each case study, including teachers, teaching resources and facilities, and instruction time, is presented in Table 2. 
Insert Table 2 about here

A notable difference in the way the participating schools organized their curricula is that the Chinese teachers tended to include about double the number of hours science instruction each week compared with the Australian teachers (Table 2). Our interviews with the Chinese science teachers revealed that the number of hours allocated to science per week is based on the Instructional Time Planning For Compulsory Education Courses, issued by the Department of Education, Hunan Province. In Australia, decisions about time spent teaching science are made at the school level and ultimately depend on the classroom teacher.

Another notable difference was that the teacher in all high and medium socioeconomic case studies in both countries ( $\mathrm{C} 1, \mathrm{~A} 1, \mathrm{C} 2$ and A2) described themselves as a 'science specialist' (Table 2) and spent considerable time teaching science in their personal timetable. In comparison, the teacher from the Australian low socioeconomic case study described himself as generalist elementary teacher but said that he had some science background from his high school education. The teacher from the low socioeconomic Chinese case study said her area of expertise is Chinese literacy (Table 2). The Chinese high socioeconomic case study (C1) was the only school to have a science laboratory, two other schools (A1 and C2) had science storerooms (Table 2).

All teachers in the Chinese case studies said they were required to use either the national or provincial versions of a mandated science textbook to guide their lessons (Table 2). According to the Chinese science teachers, all science textbooks have a student's book and a teacher's book. The teacher's book provides guidelines on how the lesson should be prepared and taught, including the learning outcomes, materials needed for activities, and lesson steps. Table 3 provides an overview of the information included in the teacher's book for each of the lessons observed in each of the Chinese case studies. There are no mandated instructional materials for science teaching in elementary schools in Australia. Teachers have the responsibility of determining which, if any, science textbooks are used by teachers and students. The teachers in the Australian case study schools said they generally prepared their own teaching materials including classroom worksheets. Only the teacher in the Australian low socioeconomic case study (A3) used student worksheets from a textbook called Transition Science, An Integrated Curriculum Approach, Science 7-8 (Curriculum Branch Education Department of Western Australia, 1986). Teachers from the low socioeconomic schools in both countries explained that they had difficulty preparing the materials and equipment required for hands-on activities and they could only use whatever was available to them in the near locality.

Insert Table 3 about here

\section{The curriculum-in-action}

In this section the findings from the lesson observation are provided in Table 4. The topics of the science lessons observed in the six case study schools varied considerably and included the expansion and contraction of air (C1), building bridges (A1), magnetism (C2), bird watching (A2), water pollution (C3), and plant growth and sunlight (A3). Despite the diversity, we noted important trends in the lessons by scrutinizing the findings and comparing what we saw with what would be expected based on the formal science curriculum in each country.

Insert Table 4 about here. 
Our observations indicated that teachers in the high and medium socioeconomic case studies in both China and Australia $(\mathrm{C} 1, \mathrm{C} 2, \mathrm{~A} 1$, and A2) all conducted practical activities as part of their lessons but the teachers in the low socioeconomic case studies (C3 and A3) did not (Table 4). Another observation was that the practical activities in the Chinese high and medium socioeconomic case studies (C1 and C2) were closed activities, that is, the expected outcome of the activity was known and planned by the teacher, for example, exploring known magnetic properties (Table 4). The actual processes of the lesson observed in each Chinese case study (Table 4) indicated that the science lessons delivered in $\mathrm{C} 1$ and $\mathrm{C} 2$ were in alignment with the teacher's book with only minor modifications (Table 3 ).

Practical activities observed in the high and medium socioeconomic case studies (A1 and A2) in Australia were open-ended, that is, the findings of the investigations were unknown and each group of students or student was likely to come up with their own unique finding/outcome. For example, A1 students were required to design and build idiosyncratic bridges (Table 4).

Group work was a common feature in the lessons observed in high and medium socioeconomic case studies in both China and Australia (Table 4). For example, students in C1 worked in small groups to conduct an experiment on the expansion and contraction of air. While students in the low socioeconomic case study in Australia (A3) worked in pairs to discuss dependent and independent variables, this lesson did not involve the students in conducting practical work or solving problems in groups (Table 4). Further, the teachers in both low socioeconomic schools required students to individually write notes, either from the blackboard or on a worksheet (Table 4). The only lesson that did not involve small group work at all was the lesson observed in the Chinese low socioeconomic case study (C3) where students worked almost the entire lesson either individually or as a whole class (Table 4). According to the guide for lesson preparation, this 'water pollution' lesson was supposed to have elements of picture demonstration, group discussion, and group work on a simple water purification experiment (Table 3); however, these elements were missing.

A number of other pedagogies were noted in the observed lessons (Table 4). For example, at the beginning of some lessons, teachers asked a number of questions to help students recall what they did in the previous lesson (C2, C3, A3) (Table 4). Some teachers engaged students with an hypothesis $(\mathrm{C} 1)$, or challenging question $(\mathrm{C} 2)$, and then drew their attention to a new task they were going to solve in the observed lesson (Table 4). Other teachers engaged students at the beginning of the lesson with pictures (A1), a guest speaker (A2), a demonstration (C1), and an arm-wrestle role play to represent 'strong' and 'weak' magnetic forces (C2) (Table 4).

There were a couple of pedagogical strategies observed in the case study classrooms that seemed to be different between the Chinese and Australian schools. For example, students in the Chinese high and medium socioeconomic case studies ( $\mathrm{C} 1$ and $\mathrm{C} 2$ ) chanted important facts at the end of their lessons on the expansion and contraction of air and magnetism (Table 4), but chanting was not observed in any of the Australian elementary science lessons. Another difference noted was that student presentations of work were evident in two of the observed lessons in Australia, A1 and A2 (Table 4), but not in any of the lessons in Chinese schools.

\section{The experiential curriculum}

In order to understand the experiential curriculum as perceived by the students (Research Question 3), items on the student questionnaire probed how frequently they perceived participating in nine activities as listed in the Methods section. In this section of the findings, the comparative, between country, Chinese and Australian student perceived frequencies of all nine 
activities are initially considered. Subsequently, the patterns and trends among the Chinese case studies (C1, C2, and C3) and the Australian case studies (A1, A2, and A3) are explored.

Between country comparisons of classroom learning activities

The Mann-Whitney U Test indicated that the participating Chinese students, on average, perceived that they participated in the majority of activities in the student questionnaire (8 of 9) more frequently than the participating Australian students (Table 5). Additionally, the MannWhitney $U$ Test showed that the Chinese Grade 6 students reported significantly higher frequencies of participating in the following activities compared with their Australian counterparts: making observations, watching the teacher conduct a science experiment, reading science books, memorizing science facts, giving an explanation about what they are learning, and working on science problems on their own. The effect sizes indicated the magnitude of these statistically significant differences between the groups for these activities were all medium or large (Table 5). No statistical difference was found between Chinese and Australian students reported frequencies of designing a science experiment, conducting a science experiment, and working in groups on a science experiment (Table 5).

According to the Chinese Grade 6 students, the three most frequent activities they participated in during science class were writing or giving an explanation of what they were learning, reading books about science, and watching the teacher conduct a science experiment (Table 5). Students also reported more frequently memorizing science facts and working on science problems on their own than other learning activities such as making observations, working in small groups on an experiment, and conducting a science experiment. The least frequent activity that Chinese students reported was designing a science experiment (Table 5).

In contrast with the Chinese students, the three most frequent activities reported by the participating Australian Grade 6 students were designing a science experiment, conducting a science experiment, and working in small groups on a science experiment (Table 5). Students also reported more frequently making observations and working on science problems on their own than other activities, such as memorizing science facts and watching the teacher conduct a science experiment. The two least frequent activities that Australian students reported were reading books about science and giving an explanation of what they are learning (Table 5).

Insert Table 5 about here

\section{Within country comparisons of learning activities}

The results from the Kruskal-Wallis Test (Table 6) indicated that, across the Chinese case studies of different socioeconomic status, statistically significant differences were found in the following activities: watching the teacher conduct a science experiment, doing a science experiment, working in small groups on a science experiment, memorizing science facts, and working out science problems on their own. Further, the Mann-Whitney U Test (Table 7) revealed strong trends across the high, medium, and low socioeconomic case studies. The higher the school's socioeconomic status, the greater the students' reported frequencies of being engaged in watching the teacher conduct a science experiment, conduct a science experiment themselves, and work in small groups on a science experiment. The lower the school's socioeconomic status, the more often students perceived they were engaged in memorizing science facts. Students from the medium and low socioeconomic schools (C2 and C3) reported higher frequencies of working out science problems on their own compared with the students from the high socioeconomic school 
(C1). The students in the low socioeconomic school (C3) reported the lowest perceived frequency of participating in group work. Our classroom observations were consistent with this finding with the children in the low socioeconomic case study in China the only ones not to be observed participating in group work.

Across the Australian case studies of different socioeconomic status, the Kruskal-Wallis Test indicated statistically significant differences in students' perceptions of participating in the following activities: designing a science experiment, conducting a science experiment, and writing or giving an explanation of what they were learning (Table 6). Further, the MannWhitney U Test of these three activities (Table 7) revealed that the higher the school's socioeconomic status, the more often students reported being engaged in designing a science experiment and conducting a science experiment. Significant differences in students' perceptions of participating in these two activities were evident between the high and medium socioeconomic case studies, and between the high and low socioeconomic case studies (Table 7). Table 7 also shows that students from the high and medium socioeconomic case studies (A1 and A2) reported significantly higher frequencies of writing or giving explanations of what they were learning than the students from the low socioeconomic case study (A3). Australian students in all schools were just as likely as each other to perceive working in groups on a science experiment and this was confirmed by our observations.

Insert Table 6 and Table 7 about here

\section{Discussion}

The data on the organization of the formal curriculum in China and Australia revealed cultural and socioeconomic complexities. In China we found considerably more centralized control of how science is taught in elementary schools. This was indicated by standardized instructional time for science teaching, as well as standardized science textbooks corresponding to the national science curriculum. The teacher's books provide detailed guidelines for lesson preparation and implementation. Meanwhile, such standardization was not evident in Australia with the teachers expressing more autonomy in the classroom. Aldridge et al. (1999) observed Grade 8 and Grade 9 science classes in Australia and Taiwan and found that the majority of Australian teachers tried to use a variety of innovative and creative teaching methods and had considerable freedom to decide how the content of the curriculum was delivered.

Across both countries, high and medium socioeconomic case studies had science specialist teachers and the low socioeconomic schools had teachers who did not self identify as being a science specialist. Research has shown that teachers' science content knowledge influences their instructional practice and the classroom culture (Appleton, 2007). Consequently, it is reasonably possible that because the teachers in the low socioeconomic case study schools were not specialists, they had a diminished capacity to deliver science lessons that aligned with the formal curriculum. This was illustrated in the observation in the low socio-economic class in China which was taught by a Chinese literacy teacher who avoided the group work recommended in the teacher's book.

Ideally, "excellent facilities, equipment and resources support teaching and learning" of science (Goodrum, Hackling, \& Rennie, 2001, p. vii). Unlike the high and medium socioeconomic schools that had a science laboratory and a science storeroom respectively, the 
low socioeconomic case study school in China was not equipped with such facilities. Another factor related to resources is that the Chinese case study classrooms had a considerably higher student to teacher ratio compared with the Australian case studies. It is possible that the large number of students in the Chinese classrooms may explain the observed tendency for Chinese teachers, but not Australian teachers, to use chanting as a teaching strategy and the observed tendency for Australian teachers, but not Chinese teachers, to allow students to make individual or group presentations to the class. Goodrum et al. (2001) said that in the ideal classroom, "class sizes make it possible to employ a range of teaching strategies and provide opportunities for the teacher to get to know each child as a learner and give feedback to individuals" (p. vii). Having a large class or a small class can impact instructional choices (Martin et al., 2008).

Our findings revealed that the Chinese teachers reported teaching elementary science about double the time reported by the Australian teachers and a consistent finding was that the Chinese students perceived participating more frequently than the Australian students in eight of nine activities listed on the student survey. In other words, much more science was reported to be conducted in the Chinese case studies compared with the Australian case studies. With twice the amount of teaching and learning of science happening, it would be expected that the students would have considerably better science achievement, which research in these settings demonstrated was not the case (Tao et al., 2012b). In fact, the students in the Chinese medium and low socioeconomic case studies were underperforming compared with their Australian counterparts. This finding may be of concern for the Chinese case studies. Does it mean that much of what was happening in the Chinese case study classrooms, in particular those in the medium and low socioeconomic schools, was ineffective or not consistent with contemporary curriculum reform and corresponding assessments? This issue warrants further investigation because issues related to whether increased instructional time in science results in increased achievement, or whether the nature of what occurs in the increased time makes a difference have important policy implications.

The results from the student questionnaire, presented in Table 5, show a complete mirror image of Chinese and Australian students' perceptions of the activities they most frequently participate in, and those they least frequently participate in during elementary science lessons. On the surface, this would indicate radically different approaches to the teaching and learning of science in these countries; however, we found the differences between the countries were not as straight forward. When we examined the data more closely, complexities related to the socioeconomic status of the schools and alignment (or lack thereof) between the formal, inaction, and experiential curricula became apparent.

Of the nine activities listed on the student questionnaire, the top two most frequent activities in this study for the Chinese Grade 6 students when learning about science were writing or giving an explanation, and reading books about science. These two activities were the least frequent activities for the Australian students. There was very little variation within the schools of different socioeconomic status in China with regard to students' perceived frequency of reading books or writing in science. These findings for the Chinese Grade 6 students aligned with China's cultural background as described earlier. Confucian philosophy encourages Chinese people to revere books and strongly advocates the use of book work for education (An, 2004; Li, 2004). We note tension between the traditional cultural values and the new approaches to science education promoted by the Chinese Ministry of Education who advocated in 2001 that educational approaches should rely less on imparting book knowledge (Ministry of Education [China], 2001). In contrast, Australia is probably less culturally attached to book work in science. 
According to the TIMSS 2007 Report (Martin et al., 2008) only four percent of Australian teachers reported that they used a textbook as a primary resource. Our finding that the participating Australian children reported rarely participating in writing or reading a book about science, is consistent with the cultural background in Australian schools influenced by theorists such as Bruner (1966) and Vygotsky (1978). These theorists focused on the importance of the contextual and social aspects of learning over the nature of learning that is more likely to occur through pedagogies that involve students in individual reading and note taking. An interesting complexity in our study is that the teacher in the low socioeconomic case study school was the only Australian teacher to use a textbook in the observed lessons. This finding is interesting because textbook use is more consistent with behaviorist, transmissive approaches to education, which were the cultural norm in Australia in the 1970s and 1980s (Scott, 2008).

Memorizing science facts was the fourth most frequent activity for Chinese students on the questionnaire and the sixth most frequent activity for Australian students; however, the Chinese students perceived participating in this activity far more frequently than the Australian students. We also noticed that in two of the three Chinese lessons (in the high and medium socioeconomic case studies), students were involved in chanting important information during their science lesson, but this did not happen in any of the observed lessons in Australia. Memorizing, like book work, is an educational activity that is regarded by Confucian philosophy as an appropriate educational strategy (Leng, 2005). However, when we look more closely at the degree to which students within the Chinese case studies felt they participated in memorization of science facts, we noticed considerable within country disparities. The students from the high socioeconomic case study, who are the highest achieving of the Chinese students (Tao et al., 2012b), reported significantly less frequently participating in memorizing science facts than their peers in the medium and low socioeconomic cases studies. This within country disparity suggests that the teaching and learning activities in the high socioeconomic case study are more consistent with those advocated by the Chinese Ministry of Education who called for an end to the overemphasis on repetitive rote-learning (Ministry of Education [China], 2001). There were no within country differences with regard to memorizing science facts in Australia.

Research has shown that high quality dialogue through small group work in the classroom has the potential to increase student interest in learning and achievement in science (e.g. Mercer $\&$ Littleton, 2007). There was no significant difference on the students' questionnaire in the overall frequency with which the Chinese and Australian Grade 6 children reported working in small groups on science experiments. However, the Chinese children ranked this activity seventh most frequent and the Australian children third most frequent activity of nine. There also was strong within country disparity on this item in China with the students in the high socioeconomic school significantly more likely to report participating in small group work on a science experiment than the children in the medium and low socioeconomic schools. Further, a significant within-country difference was found in China on the item about independently working on science problems, with the students in the medium and low socioeconomic schools more likely to report participating in such individual, independent work.

Teamwork and cooperative learning were advocated by the Chinese Ministry of Education with their move to the new curriculum in 2001 (Ministry of Education [China], 2001). Our findings support our assertion, made above, that the students in the high socioeconomic school in China are exposed to a curriculum that is more consistent with China's formal, documented curriculum. Confucius philosophy teaches that while education is a community responsibility, learning is about self-cultivation, an individual activity (Leng, 2005). Confucian heritage 
children are not accustomed to being encouraged to talk with other students within the classroom, or to participating in cooperative learning (Change \& Mao, 1999), and it is possible that adapting to the use of group work may be more challenging for the teachers and students in the lower socioeconomic case studies. Individual work, more consistent with Confucian philosophy, may be a viable and attractive alternative teaching approach for the teacher in the lower socioeconomic school in China.

There is a considerable body of research showing that inquiry-based instruction, advocated in both the Chinese and Australian curriculum documents, potentially provides significant advantages for science learning and is positively related to student achievement in science (Cobern et al., 2010; Fogleman, McNeill, \& Krajcik, 2011). The findings from this study showed that Chinese students perceived more frequently participating in passive, closed practical activities, such as making observations and watching the teacher do an experiment. In contrast, the Australian students reported spending a greater proportion of their science lessons participating in active, open tasks, such as conducting and designing science experiments. Within both countries, there were disparities, based on the socioeconomic status of the case study schools with regard to practical and inquiry-oriented activities. In China the reported frequency of observing and participating in practical activities increased with socioeconomic status, as did the reported frequency of participating in active, open inquiry-based classroom activities in Australia.

The Western Australian curriculum (Curriculum Council, 1998) requires students to learn how to design and conduct science investigations and that students be taught investigative skills so that they can make their own decisions about what data to collect and methods to use. Science educators in Australia have argued for a number of years that students need to participate in open investigation work if they are to develop the investigation skills, problem solving abilities, and understandings of evidence that are at the heart of scientific literacy (e.g. Hackling, 1998). These arguments are consistent with the work of theorists, like Bruner, who argued that students make sense of scientific knowledge by sharing and participating in scientific culture, including participating in inquiry (Scott, 2008). Despite these strong cultural factors, disparities in the degree of implementation of the inquiry aspects of the formal science curriculum were evident across schools of different socioeconomic status in the Australian case studies.

In the Chinese national curriculum (Ministry of Education [China], 2001), students are encouraged, but not required, to plan their own investigations as part of their homework or extracurricular activities. The standardized curriculum in China requires teachers to conduct recipe-style practical activities, but not open inquiry activities where the students are actively involved in asking their own questions or designing their own investigations. This is a conservative approach to the curriculum which, it could be argued, does not entirely reflect the reform documents which promote social development and science inquiry (Division of Primary Education Ministry of Education [China], 2002). Confucian teachings require students to be active, thoughtful learners (An, 2004; Li, 2004), and emphasize deductive thinking (Cai, 2002). While deductive thinking is one important aspect of scientific inquiry, an inquiry approach to teaching science is less about transmitting information and explaining concepts in an authoritarian manner, and more about the teacher facilitating students thinking and enabling them to actively participate in an inquiry process (Anderson, 2007). The findings from this study again indicate discord between the traditional Confucian approaches to teaching and learning in China that are deductive and the nature of the reform documents that advocate an inquiry approach to teaching and learning. Moreover, it is possible that the challenges of incorporating 
hands-on, practical tasks in the classroom rendered the culturally acceptable, Confucian-based transmission style of teaching science more attractive to the teachers in the lower socioeconomic schools than the requirements of the reformed, formal curriculum (Anderson, 2007).

\section{Conclusion}

This research investigated the implementation of the elementary science curriculum in China and Australia in the context of globalization of curriculum reform that advocates scientific inquiry as the goal of science education, and student-centered and inquiry-based pedagogies. We found that the teaching and learning of elementary science was centrally controlled in China where teachers used curriculum-based textbooks for students and followed scripted lessons from the teacher's book. In Australia, teachers had more freedom to design their own science lessons. Despite the central control, our findings indicated that in contrast with reform documents in China, the inaction and experiential curricula in elementary science were strongly influenced by traditional Confucian philosophy. Participating Chinese students reported more of their science lessons being taken up by activities such as writing, reading textbooks, memorizing facts, and working out science problems on their own. In Australia, where there has been a longer historical influence from social-constructivist theorists such as Bruner and Vygotsky, the in-action and experiential curriculum more closely aligned with the formal curriculum documents. Participating students in Australia reported that their lessons were more likely to involve activities such as designing, planning, and doing science experiments, and working in small groups.

While the cultural explanations for the differences in in-action and experiential curricula between the two countries are plausible, our findings also revealed a number of complexities with regard to the socioeconomic status of the schools in which the case studies were conducted. The holistic picture we ascertained from the findings was that in both countries, socioeconomic status was an important variable that impacts the implementation of global reform approaches to science education including inquiry-oriented and student-centered pedagogies. Our findings indicated that the higher the socioeconomic status of the schools in which our case studies were conducted, the more likely the implemented and experienced classroom activities were consistent with the relevant formal curriculum and vice versus. Our findings also indicated that the within country differences amongst schools of different socioeconomic status in China were more apparent than the within country differences in Australia. We speculate that this cross national difference may be due to Australia having a longer educational cultural history with theorists advocating teaching and learning practices that are consistent with the current Australian elementary science curriculum documents. China has had a more recent, and possibly more abrupt, transition through the reform process. It is possible that for the lower socioeconomic schools in China, teaching approaches consistent with Confucian philosophy are viable, culturally acceptable alternatives. Moreover, it is probable that the large class sizes in China, compounded with limited access to resources of various kinds in the lower socioeconomic schools, magnified the viability of culturally traditional approaches to science education.

We acknowledge that the small samples of teachers and students that participated in our six case studies in China and Australia are not representative of all children and teachers in either of these vast countries. In light of the findings of the current research, however, it may be helpful for future research to examine more closely the curriculum-in-action, and experiential curriculum 
in Chinese, Australian and other nations' elementary science classrooms. Future research should more deeply examine teachers' pedagogical content knowledge, classroom discourse, and the interactions between teachers and students in order to better understand the way that crosscultural and socioeconomic differences impact on the implementation of the science curriculum. Our findings raise questions about the transplantation of globalized approaches to the science curriculum and the impact these approaches have on students in countries with different cultures. In particular, our findings raise questions about whether such transplantation widens the achievement gap between students in schools of different socioeconomic status. Finally, investigating the advantages and disadvantages of maintaining aspects of traditional cultural approaches to teaching and learning in contextualized classroom settings may be of considerable value to educators in developing nations.

\section{References}

Adamson, B. (2012). International comparative studies in teaching and teacher education. Teaching and Teacher Education, 28(2012), 641-648.

Aldridge, J. M., Fraser, B. J., \& Huang, T. C. (1999). Investigating classroom environments in Taiwan and Australia with multiple research methods. Journal of Educational Research, 93(1), 48-61.

Alexander, R. (2000). Culture and pedagogy: International comparisons in primary education. Oxford: Blackwell Publishers Ltd.

Allen, P. J., \& Bennett, K. (2008). SPSS for the health and behavioural sciences. South Melbourne, Australia: Thomson.

An, S. H. (2004). Capturing the Chinese way of teaching: The learning-questioning and learning-reviewing instructional model. In L. H. Fan, N. Y. Wong, J. F. Cai \& S. Q. Li (Eds.), How Chinese learn mathematics: Perspectives from insiders. London: World Scientific Publishing.

Anderson, R. D. (2007). Inquiry as an organizing theme for science curricula. In S. K. Abell \& N. G. Lederman (Eds.). Handbook of Research on Science Education (pp. 807-830). Mahwah, NJ: Lawrence Erlbaum.

APEC Human Resources Development Working Group. (2006). Innovation on Science Curriculum in China. Retrieved December 12th, 2011, from http://hrd.apec.org/index.php/Science_Curriculum_and_Instruction

Appleton, K. (2007). Elementary science teaching. In S. K. Abell \& N. G. Lederman (Eds), Handbook of research on science education (pp. 493-536). Mahwah, New Jersey: Lawrence Erlbaum.

Australian Bureau of Statistics. (2011). Western Australia State Statistical Indicators. Retrieved November 7th, 2011, from

http://www.abs.gov.au/ausstats/abs@.nsf/Lookup/by\%20Subject/1367.0 2011 Main\%20Features Weste rn\%20Australia 19

Australian Curriculum Assessment and Reporting Authority. (2011). The Australian curriculum: Science. Retrieved May 20, 2011, from http://www.australiancurriculum.edu.au/Science

Berben, L., Sereika, S. M., \& Engberg, S. (2012). Effect size estimation: Methods and examples. International Journal of Nursing Studies, 49, 1039-1047.

Biggs, J. B. (1966). Western misconceptions of the Confucian-heritage learning culture. In D. A. Watkins \& J. B. Biggs (Eds.), The Chinese learner: cultural, psychological and contextual influences (pp. 45-68). Hong Kong: Comparative Education Research Centre.

Bruner, J. S. (1966). Toward a theory of instruction. Cambridge, MA: Harvard University Press.

Chang, C. Y., \& Mao, S. L. (1999). Comparison of Taiwan science students' outcomes with inquiry-group versus traditional instruction. Journal of Educational Research, 92(6), 340-346.

Chen, Q. (2004a). Reflection upon the current primary science education. Beijing Education, 7, 15-17 [in Chinese].

Chiu, M.-H., \& Duit, R. (2011). Globalization: Science education from an international perspective. Journal of Research in Science Teaching, 48(6), 553-566.

Cai, J. F., \& Lester, F. (2007). Contributions from cross-national comparative studies to the internationalization of mathematics education: Studies of Chinese and U.S classrooms. In B. Atweh, A. C. 
Barton, M. Borba, N. Gough, C. Keitel, C. Vistro-Yu \& R. Vithal (Eds.), Internationalisation and globalisation in mathematics and science education (pp. 269-283). Dordrecht, The Netherlands: Springer.

Cobern, W. W., Schuster, D., Adams, B., Applegate, B., Skjold, B., Undreiu, A., et al. (2010). Experimental comparison of inquiry and direct instruction in science. Research in Science and Technological Education, 28(1), 81-96.

Cogan, L. S., Wang, H. A., \& Schmidt, W. H. (2001). Culturally specific patterns in the conceptualization of the school science curriculum: insights from TIMSS. Studies in Science Education, 36, 105-133.

Coll, R. K., \& Taylor, N. (2012). An international perspective on science curriculum development and implementation. In B. J. Fraser, K. G. Tobin, \& C. J. McRobbie (eds.), Second international handbook of science education (Vol II, pp. 771-782). Dordrecht, Netherlands: Springer.

Cohen, J. (1988). Statistical power analysis for the behavioral sciences (2nd ed.). Hillsdale, NJ: Erlbaum.

Cortazzi, M. (1998). Learning from Asian lessons: Cultural expectations and classroom talk. Education 3-13, 26(2), 42-49.

Curriculum Branch Education Department of Western Australia. (1986). Transition science 7-8: An integrated curriculum approach. Perth, Western Australia: Government Printer, WA.

Curriculum Corporation (1994). A statement on science for Australian schools. Melbourne: Author.

Curriculum Council Western Australia. (1998). Curriculum Framework Learning Statement for Science. Retrieved 20 March, 2009, from http://www.curriculum.wa.edu.au/internet/Years_K10/Curriculum_Framework

Dawson, V., \& Venville, G. (2012). The Australian science curriculum. In G. Venville \& V. Dawson (Eds.), The art of teaching science: For middle and secondary schools (pp. 122-135). Sydney: Allen and Unwin.

Department of Education of Hunan Province. (2011). Educational Statistics in 2010. Retrieved November 7th, 2011, from http://gov.hnedu.cn/web/0/201109/08173319740.html

Dillon, S. (2010). Top test scores from Shanghai stun eductors. New York Times. Retrieved from http://www.nytimes.com

Ding, B. (2008). Learning from other countries: A critical examination of the current primary science curriculum reforms in mainland China. In R. K. Coll \& N. Taylor (Eds.), Science educational in context: An international examination of the influence of context on science curricula development and implementation (pp. 343-352). Rotterdam: Sense Publishers.

Division of Primary Education Ministry of Education [China]. (2002). Interpretation of science curriculum standard (3-6 Grade) for full-time compulsory education. Wuhan: Hubei Education Press [in Chinese].

Fensham, P. (2007). Contextual or culture: Can TIMSS and PISA teach us about what determines educational achievement in science? In B. Atweh et al., (Eds.), Internationalisation and globalisation in mathematics and science education (pp. 151-172). Dordrecht, The Netherlands: Springer.

Fogleman, J., McNeill, K. L., \& Krajcik, J. (2011). Examining the effect of teachers' adaptations of a middle school science inquiry-oriented curriculum unit on student learning. Journal of Research in Science Teaching, 48(2), 149-169.

Gao, L. B. (1995). Cutural influences on physics education. Australia Journal of Physics 48, 259-265.

Gao, L. B. (1998). Cultural context of school science teaching and learning in the People's Republic of China. Science Education, 82(1), 1-13.

Goodrum, D., Hackling, M., \& Rennie, L. (2001). The status and quality of teaching and learning of science in Australian schools. Canberra: Department of Education, Training and Youth Affairs

Guo, C.-J. (2007). Issues in science learning: An international perspective. In S. K. Abell \& N. G. Lederman (Eds.), Handbook of research on science education (pp. 227-256). Mahwah, New Jersey: Lawrence Erlbaum.

Hackling, M. W. (1998). Working scientifically: Implementing and assessing open investigation work in science. Perth, Australia: Education Department of Western Australia.

Hu, W. P., Han, Q., \& Liu, J. W. (2007). Investigation into and thoughts of the current situation of the implementation of new curriculum of science in the primary schools. Theory and Practice of Education, 27(3), 58-63 [in Chinese].

Hunan Provincial Government. (2011). Brief Introduction of Hunan Province. Retrieved November 7th, 2011, from http://enghunan.gov.cn/AboutHNprovince/Snapshot/Introducton/ 
Krajcik, J. S., \& Sutherland, L. M. (2010). Supporting students in developing literacy in science. Science, 328(5977), 456-460.

Kyriakides, L. (2006). Using international comparative studies to develop the theoretical framework of educational effectiveness research: A secondary analysis of TIMSS 1999 data. Educational Research and Evaluation, 12(6), 513-534.

Leng, H. (2005). Chinese cultural schema of education: Implications for communication between Chinese students and Australian educators. Issues in Educational Research, 15(1), 17-36.

Li, H. (2004). A brief history of primary science curriculum reform in China. Beijing: People's Education Press [in Chinese].

Lokan, J., Hollingsworth, H., \& Hackling, M. W. (2006). Teaching science in Australia: Results from the TIMSS 1999 video study. Retrieved 9 February, 2010, from http://www.acer.edu.au/documents/TIMSS TVidSciAujzMar06FINAL2.pdf

Martin, M. O., Mullis, I. V. S., \& Foy, P. (2008). TIMSS 2007 international science report: Classroom characteristics and instruction. Retrieved May 19, 2011, from http://timss.bc.edu/TIMSS2007/PDF/T07_S_IR_Chapter4.pdf

Mercer, N., \& Littleton, K. (2007). Dialogue and the development of children's thinking: A sociocultural approach. Milton Park, UK: Routledge.

Ministerial Council on Education Employment Training and Youth Affairs. (2008). National Declaration On Educational Goals For Young Australians-Draft. Retrieved December 12th, 2011, from http://www.curriculum.edu.au/verve/_resources/Draft_National_Declaration_on_Educational_Goals_for_ Young_Australians.pdf

Ministry of Education [China]. (2001). Guidelines for Curriculum Reform of Basic Education. from http://www.moe.edu.cn/publicfiles/business/htmlfiles/moe/moe_309/200412/4672.html

Ministry of Education [China]. (2010). National Outline for Medium and Long-term Education Reform and Development 2010-2020. from http://www.gov.cn/jrzg/2010-07/29/content_1667143.htm (in Chinese)

Nall-Bird, J. (2004). Is school science, science? Teaching Science, 50(3), 6-9.

OECD. (2011). Shanghai and Hong Kong: Two distinct examples of education reform in China. Lessons from PISA for the United States: Strong performers and successful reformers in education Retrieved November 17th, 2011, from http://dx.doi.org/10.1787/9789264096660-en

Patton, M. Q. (2002). Qualitative research and evaluation methods (3rd ed.). London: Sage Publications.

Perry, L., \& McConney, A. (2010a). Does the SES of the school matter? An examination of socioeconomic status and student achievement using PISA 2003. Teachers College Record, 112(4), 1137-1162.

Perry, L., \& McConney, A. (2010b). School socio-economic composition and student outcomes in Australia: Implications for educational policy. Australian Journal of Education, 54(1), 72-85.

Qian, X., \& Smyth, R. (2005). Measuring regional inequality of education in China: Widening coast-inland, or widening rural-urban gap? Australian Business and Economics Research Unit (ABERU) discussion paper No 12 Retrieved March 12, 2012, from http://www.buseco.monash.edu.au

Scott, D. (2008). Critical essays on major curriculum theorists. Milton Park, UK. Routledge.

Stigler, J. W., \& Stevenson, H. W. (1991). How Asian teachers polish each other to perfection. American Educator, 15(1), 12-21, 43-47.

Tao, Y. (2012). Chinese and Australian primary children's conceptual understanding of science: A multiple comparative case study. Unpublished doctoral thesis, University of Western Australia, Perth. Western Australia, Australia.

Tao, Y., Oliver, M., \& Venville, G. (2012a). Chinese and Australian Year 3 children's conceptual understanding of science: A multiple comparative case study. International Journal of Science Education, 34(6), 879-901.

Tao, Y., Oliver, M., \& Venville, G. (2012b). Long-term outcomes of early childhood science education: Insights from a cross-national comparative case study on conceptual understanding of science. International Journal of Science and Mathematics Education.

Thomson, S., Ainley, J., \& Nicholas, M. (2007). Australia. TIMSS 2007 Encyclopedia: A guide to mathematics and science education around the world. Volume 1 A-L. Retrieved 14 May, 2009, from http://timss.bc.edu/TIMSS2007/PDF/T07_Enc V1.pdf 
Thomson, S., \& De Bortoli, L. (2008). Exploring scientific literacy: How Australia measures up. Retrieved September 30, 2010, from http://www.acer.edu.au/documents/PISA2006_Report.pdf

Thomson, S., de Bortoli, L., Nicholas, M., Hillman, K., \& Buckley, S. (2011). Challenges for Australian Education: Results from PISA 2009. Canberra: Australian Council for Educational Research, ACER Press.

Tsang, M. C., \& Ding, Y. (2005). Resource utilization and disparities in compulsory education in China. China Review, 5(1), 1-28.

Tytler, R. (2012). Constructivist and socio-cultural views of teaching and learning. In G. Venville \& V. Dawson (Eds.), The art of teaching science: For middle and secondary schools (pp. 23-40). Sydney: Allen and Unwin.

van den Akker, J. (1998). The science curriculum: Between ideals and outcomes. In B. J. Fraser \& K. G. Tobin (Eds.), International handbook of science education (pp. 421-447). Dordrecht: Kluwer Academic Publishers.

Vermeer, A. (2002). Teaching inductive reasoning in primary education. Developmental Review, 22(2), 211241.

Vygotsky, L. S. (1978). Mind in society: The development of higher psychological processes. Cambridge: Harvard University Press.

Walker, R., \& Adelman, C. (1975). Guide to classroom observation. London: Routledge.

Wei, Y. (2008a). Minutes of the first board meeting on proposed national primary science curriculum. Retrieved October 8, 2008, from http://nsse.handsbrain.com/article.php/296 [in Chinese].

Wei, Y. (2008b). Recovering science education in primary Year 1 and Year 2. Retrieved October, 8, 2008, from http://nsse.handsbrain.com/article.php/36 [in Chinese]

Yin, R. K. (2003). Case study research: design and methods (3rd ed.). California: Sage Publications

Zhong, Q-q. (2006). Curriculum reform in China: Challenges and reflections. Frontiers of Education in China, $3,37-382$.

Zhou, Z. D. (2006). Implementation of science curriculum in primary schools in Hunan Province: A survey report in 2005. Science Lesson, 10, 10-13 [in Chinese]. 
Table 1. Profiles of the Schools in which the Case Studies were Conducted

\begin{tabular}{cccccccc}
\hline Country & $\begin{array}{c}\text { School } \\
\text { code }\end{array}$ & SES & Location & Sector & $\begin{array}{c}\text { Year } \\
\text { range }\end{array}$ & $\begin{array}{c}\text { Student } \\
\text { population }\end{array}$ & $\begin{array}{c}\text { Average } \\
\text { Class } \\
\text { size }\end{array}$ \\
\hline China & C1 & high & city & public & $1-6$ & 1100 & 45 \\
Australia & A1 & high & city & public & K-7 & 500 & 30 \\
China & C2 & medium & suburb & private & $1-6$ & 1200 & 40 \\
Australia & A2 & medium & suburb & private & K-7 & 450 & 26 \\
China & C3 & low & semi-rural & public & Pre K-6 & 700 & 50 \\
Australia & A3 & low & semi-rural & public & K-7 & 630 & 30 \\
\hline
\end{tabular}

Table 2. An Overview of the Science Teaching Context in Each Case Study

\begin{tabular}{|c|c|c|c|c|}
\hline $\begin{array}{l}\text { Case } \\
\text { study }\end{array}$ & Teacher & $\begin{array}{l}\text { Textbook/ } \\
\text { resources }\end{array}$ & $\begin{array}{l}\text { Science instruction } \\
\text { time }\end{array}$ & $\begin{array}{l}\text { Teaching } \\
\text { facilities }\end{array}$ \\
\hline $\mathrm{C} 1$ & science specialist & science textbook* & 2 hours/week & laboratory \\
\hline A1 & science specialist & prepared by teacher & 1-2 hours/fortnight & $\begin{array}{c}\text { classroom and } \\
\text { storeroom }\end{array}$ \\
\hline $\mathrm{C} 2$ & science specialist & science textbook* & 3 hours/week & $\begin{array}{c}\text { classroom and } \\
\text { storeroom }\end{array}$ \\
\hline $\mathrm{A} 2$ & $\begin{array}{l}\text { generalist with some } \\
\text { science background }\end{array}$ & prepared by teacher & 1.5 hours/week & classroom \\
\hline $\mathrm{C} 3$ & Chinese literacy teacher & science textbook** & 3 hours/week & classroom \\
\hline A3 & generalist & science textbook & 1-2 hours/fortnight & classroom \\
\hline
\end{tabular}


Table 3. Guidelines for Lesson Preparation from the Teacher's Book used in the Chinese Case Studies

\begin{tabular}{|c|c|c|c|c|}
\hline $\begin{array}{l}\text { Case } \\
\text { study }\end{array}$ & Lesson topic & Lesson outcomes & $\begin{array}{l}\text { Equipment and } \\
\text { materials }\end{array}$ & Lesson steps \\
\hline $\mathrm{C} 1$ & $\begin{array}{l}\text { Expansion } \\
\text { and } \\
\text { contraction } \\
\text { of air }\end{array}$ & 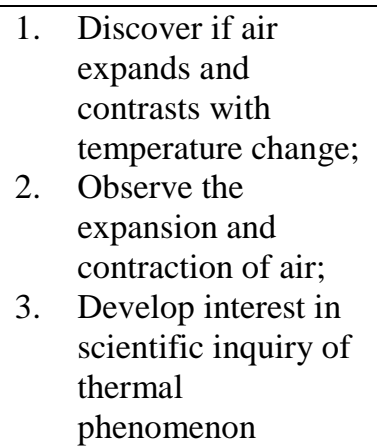 & $\begin{array}{l}\text { - } \text { Beaker } \\
\text { - L-shaped glass } \\
\text { pipe (bubbler } \\
\text { device) } \\
\text { - } \text { tripod } \\
\text { - } \text { alcohol lamp } \\
\text { - tap water } \\
\text { - cold water } \\
\text { - a balloon }\end{array}$ & $\begin{array}{l}\text { 1. Introduce the lesson by } \\
\text { asking students to make an } \\
\text { hypothesis } \\
\text { 2. Group discussion on how to } \\
\text { observe expansion and } \\
\text { contraction of air } \\
\text { 3. Design experiment with } \\
\text { teacher's guide } \\
\text { 4. Group work on experiment } \\
\text { and discussion of the findings } \\
\text { 5. Summarize the experiment }\end{array}$ \\
\hline $\mathrm{C} 2$ & Magnetism & 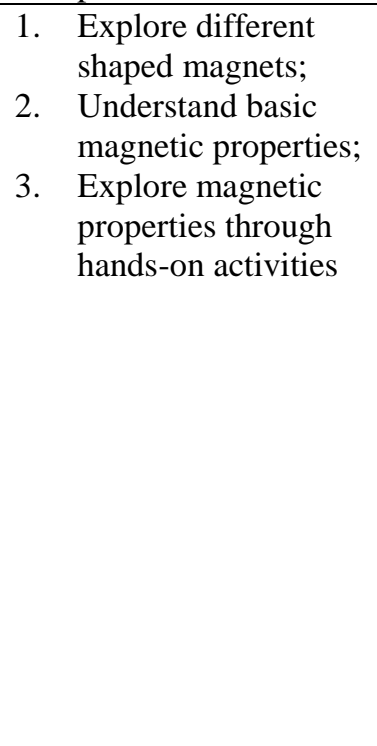 & 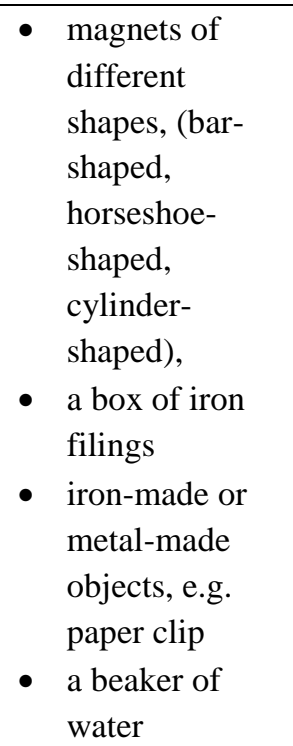 & $\begin{array}{l}\text { 1. Introduce the lesson by } \\
\text { showing students a paper clip } \\
\text { in a beaker of water } \\
\text { 2. Show students magnets of } \\
\text { different shape } \\
\text { 3. Group work to explore } \\
\text { magnetic properties and } \\
\text { magnetic field } \\
\text { 4. Group discussion of magnetic } \\
\text { properties and magnetic field } \\
\text { 5. Summarize magnetic } \\
\text { properties and get paper clip } \\
\text { out of beaker with a magnet }\end{array}$ \\
\hline $\mathrm{C} 3$ & $\begin{array}{l}\text { Water } \\
\text { pollution }\end{array}$ & $\begin{array}{l}\text { Know that water } \\
\text { pollution is caused } \\
\text { by human activities; } \\
\text { 2. Know the processes } \\
\text { of water } \\
\text { purification; } \\
\text { 3. Promote awareness } \\
\text { and responsibility } \\
\text { for protecting } \\
\text { limited water } \\
\text { resources }\end{array}$ & $\begin{array}{ll}\text { - } & \text { pictures and } \\
\text { text on water } \\
\text { pollution } \\
\text { - } \\
\text { simple filter } \\
\text { made of coke } \\
\text { bottle and fine } \\
\text { sands } \\
\text { - } \text { pond water } \\
\text { - domestic waste } \\
\text { - } \text { water } \\
\text { tap water }\end{array}$ & $\begin{array}{l}\text { 1. } \begin{array}{l}\text { Show students pictures of } \\
\text { polluted water resources and } \\
\text { discuss how they feel }\end{array} \\
\text { 2. Observe and compare tap } \\
\text { water, pond water and } \\
\text { domestic waste water } \\
\text { 3. Group work on a simple } \\
\text { water purification experiment } \\
\text { 4. } \begin{array}{l}\text { Discuss causes of water } \\
\text { pollution }\end{array}\end{array}$ \\
\hline
\end{tabular}


Table 4. Summaries of the Science Lessons Observed in Each Case Study

\begin{tabular}{|c|c|c|c|c|}
\hline $\begin{array}{l}\text { Case } \\
\text { study }\end{array}$ & Topic & Lesson introduction & Student activity in body of lesson & Lesson conclusion \\
\hline $\mathrm{C} 1$ & $\begin{array}{l}\text { Expansion } \\
\text { and } \\
\text { contraction } \\
\text { of air }\end{array}$ & $\begin{array}{l}\text { The teacher: } \\
\text { - asked questions } \\
\text { - made an hypothesis } \\
\text { - demonstrated an } \\
\text { experiment }\end{array}$ & $\begin{array}{l}\text { The students: } \\
\text { - worked in groups and set up tripod } \\
\text { for heating a beaker of water } \\
\text { - put a bubble of water into a plunger } \\
\text { - placed the plunger into the hot } \\
\text { water and observed the bubble of } \\
\text { water } \\
\text { - placed the plunger into cold water } \\
\text { and observed the bubble of water }\end{array}$ & $\begin{array}{l}\text { The teacher: } \\
\text { - drew the students' } \\
\text { attention to the front } \\
\text { - asked the students } \\
\text { what they observed } \\
\text { The students: } \\
\text { - explained their } \\
\text { findings } \\
\text { - chanted the results }\end{array}$ \\
\hline A1 & $\begin{array}{l}\text { Building } \\
\text { bridges }\end{array}$ & $\begin{array}{l}\text { The teacher: } \\
\text { - showed pictures of } \\
\text { world famous } \\
\text { bridges } \\
\text { - gave children } \\
\text { reading materials } \\
\text { on types of bridges } \\
\text { - reviewed the } \\
\text { concept of } \\
\text { 'tension' }\end{array}$ & $\begin{array}{l}\text { The students: } \\
\text { - worked in groups and wrote down } \\
\text { the bridges they know } \\
\text { - worked individually and tested the } \\
\text { strength of different types of paper } \\
\text { - worked in pairs and felt the tension } \\
\text { by pulling and pushing each other } \\
\text { - individually designed bridges } \\
\text { - worked in groups and built bridges } \\
\text { with pop sticks, ropes, straws and } \\
\text { glue }\end{array}$ & $\begin{array}{l}\text { The teacher: } \\
\text { - gathered the students } \\
\text { back into the } \\
\text { classroom } \\
\text { - commented on the } \\
\text { bridges } \\
\text { - reviewed different } \\
\text { types of bridges } \\
\text { The students: } \\
\text { - displayed their bridges }\end{array}$ \\
\hline $\mathrm{C} 2$ & Magnetism & $\begin{array}{l}\text { The teacher: } \\
\text { - asked students } \\
\text { questions about } \\
\text { what they learned } \\
\text { in the last lesson } \\
\text { - showed students a } \\
\text { test tube filled with } \\
\text { water with a paper } \\
\text { clip in the bottom } \\
\text { - challenged children } \\
\text { to think how to get } \\
\text { the paper clip out } \\
\text { of the test tube } \\
\text { without tipping out } \\
\text { the water }\end{array}$ & $\begin{array}{l}\text { The students: } \\
\text { - worked in groups and explored } \\
\text { materials with bar magnets and } \\
\text { recorded the results } \\
\text { - came to the front of the class in } \\
\text { pairs and performed an arm wrestle } \\
\text { as an analogy of 'strong' and } \\
\text { 'weak' } \\
\text { - worked as a whole class to find the } \\
\text { strongest part of a bar magnet by } \\
\text { counting the number of paper clips } \\
\text { the teacher could hang from each } \\
\text { pole and the middle } \\
\text { - worked in groups to explore a } \\
\text { magnetic field using a magnet and } \\
\text { iron filings }\end{array}$ & $\begin{array}{l}\text { The teacher: } \\
\text { - asked students } \\
\text { which materials they } \\
\text { found magnetic } \\
\text { - summarised important } \\
\text { facts about magnets } \\
\text { - retrieved the paper clip } \\
\text { from of the test tube } \\
\text { with a magnet } \\
\text { - collected children's } \\
\text { group work report } \\
\text { sheets }\end{array}$ \\
\hline
\end{tabular}




\begin{tabular}{|c|c|c|c|c|}
\hline A2 & $\begin{array}{l}\text { Bird } \\
\text { watching } \\
\text { (Scientist in } \\
\text { Schools } \\
\text { Program) }\end{array}$ & $\begin{array}{l}\text { The teacher: } \\
\text { - invited a scientist } \\
\text { into the classroom } \\
\text { and introduced the } \\
\text { program of bird } \\
\text { watching } \\
\text { - took students to the } \\
\text { bush land located } \\
\text { directly behind the } \\
\text { school } \\
\text { The students: } \\
\text { - observed birds and } \\
\text { completed bird log } \\
\text { books }\end{array}$ & $\begin{array}{l}\text { The students: } \\
\text { - in groups of three or four created a } \\
\text { bird data base, including type of } \\
\text { bird, physical features, gender, } \\
\text { size, eating habits, numbers of } \\
\text { birds } \\
\text { - discussed in small groups a } \\
\text { specific bird that they were } \\
\text { interested in and watched } \\
\text { - presented information about } \\
\text { specific birds to the whole class } \\
\text { including a wood pigeon and a } \\
\text { pink and grey galah }\end{array}$ & $\begin{array}{l}\text { The teacher: } \\
\text { - assessed students' } \\
\text { investigation skills } \\
\text { through their } \\
\text { presentations and the } \\
\text { completeness of each } \\
\text { group's bird data base } \\
\text { - conducted a whole } \\
\text { class discussion } \\
\text { summarising the data } \\
\text { students had collected }\end{array}$ \\
\hline C3 & $\begin{array}{l}\text { Water } \\
\text { pollution }\end{array}$ & $\begin{array}{l}\text { The teacher: } \\
\text { - reviewed the } \\
\text { previous lesson by } \\
\text { asking questions } \\
\text { - wrote the topic on } \\
\text { the blackboard } \\
\text { - read from the } \\
\text { textbook while } \\
\text { students silently } \\
\text { followed the text }\end{array}$ & $\begin{array}{l}\text { The students: } \\
\text { - raised hands to respond to the } \\
\text { teacher's questions } \\
\text { - wrote down notes from the } \\
\text { blackboard in their notebooks } \\
\text { - participated in a whole class } \\
\text { discussion about the causes of } \\
\text { water pollution }\end{array}$ & $\begin{array}{l}\text { The teacher: } \\
\text { - summarised important } \\
\text { facts on the blackboard } \\
\text { - Gave students } \\
\text { homework }\end{array}$ \\
\hline A3 & $\begin{array}{l}\text { Variables in } \\
\text { a plant } \\
\text { growth } \\
\text { experiment }\end{array}$ & $\begin{array}{l}\text { The teacher: } \\
\text { - recalled the last } \\
\text { experiment on } \\
\text { plant growth } \\
\text { - asked students } \\
\text { about their findings } \\
\text { - gave out work } \\
\text { sheets and asked } \\
\text { the students what } \\
\text { variables were in } \\
\text { the experiment }\end{array}$ & $\begin{array}{l}\text { The students: } \\
\text { - worked individually using } \\
\text { dictionaries to look up the } \\
\text { meanings of dependent and } \\
\text { independent variables } \\
\text { - worked in pairs and discussed the } \\
\text { independent and dependent } \\
\text { variables in their last experiment } \\
\text { - raised hands to give their answers } \\
\text { to the teacher }\end{array}$ & $\begin{array}{l}\text { The teacher: } \\
\text { - paraphrased the } \\
\text { meaning of dependent } \\
\text { and independent } \\
\text { variable } \\
\text { - wrote students' } \\
\text { answers on the white } \\
\text { board } \\
\text { - collected the students' } \\
\text { work sheets }\end{array}$ \\
\hline
\end{tabular}


Table 5. Mann-Whitney $U$ Test of Students' Perceived Frequency of Classroom Learning Activities (between-country, N=245)

\begin{tabular}{|c|c|c|c|c|c|c|c|c|c|}
\hline & \multicolumn{9}{|c|}{ Mean rank of students' perceived frequency of classroom learning activities } \\
\hline & $\begin{array}{l}\text { Look at the } \\
\text { weather or } \\
\text { a plant } \\
\text { growing }\end{array}$ & $\begin{array}{l}\text { Watch } \\
\text { teacher do } \\
\text { a science } \\
\text { experiment }\end{array}$ & $\begin{array}{l}\text { Design or } \\
\text { plan a } \\
\text { science } \\
\text { experiment }\end{array}$ & $\begin{array}{l}\text { Do a } \\
\text { science } \\
\text { experiment }\end{array}$ & $\begin{array}{l}\text { Work in a } \\
\text { small group } \\
\text { on a science } \\
\text { experiment }\end{array}$ & $\begin{array}{l}\text { Reading } \\
\text { books } \\
\text { about } \\
\text { science }\end{array}$ & $\begin{array}{l}\text { Memorizing } \\
\text { science facts }\end{array}$ & $\begin{array}{l}\text { Write or } \\
\text { give an } \\
\text { explanation }\end{array}$ & $\begin{array}{l}\text { Work out } \\
\text { science } \\
\text { problems } \\
\text { on my own }\end{array}$ \\
\hline Chinese mean rank & 142.80 & 150.09 & 117.76 & 124.42 & 127.99 & 153.83 & 146.14 & 154.13 & 145.30 \\
\hline Australian mean rank & 96.60 & 86.89 & 129.98 & 121.10 & 116.61 & 81.89 & 92.14 & 81.50 & 93.27 \\
\hline $\begin{array}{l}\text { Asymp. Sig. } \\
\text { (2-tailed) }\end{array}$ & $.000 *$ & $.000 *$ & .162 & .706 & .200 & $.000 *$ & $.000 *$ & $.000 *$ & $.000^{*}$ \\
\hline Effect Size $(r)$ & .34 medium & .45 medium & & & & .52 large & .40 medium & .54 large & .38 medium \\
\hline
\end{tabular}


Table 6. Kruskal-Wallis Test of Students' Perceived Frequency of Classroom Learning Activities (within-country, China $n=140$; Australia $n=105$ )

Mean rank of students' perceived frequency of classroom learning activities

\begin{tabular}{|c|c|c|c|c|c|c|c|c|c|}
\hline & $\begin{array}{l}\text { Look at the } \\
\text { weather or } \\
\text { a plant } \\
\text { growing }\end{array}$ & $\begin{array}{l}\text { Watch } \\
\text { teacher do } \\
\text { a science } \\
\text { experiment }\end{array}$ & $\begin{array}{l}\text { Design or } \\
\text { plan a } \\
\text { science } \\
\text { experiment }\end{array}$ & $\begin{array}{l}\text { Do a } \\
\text { science } \\
\text { experiment }\end{array}$ & $\begin{array}{l}\text { Work in a } \\
\text { small group } \\
\text { on a science } \\
\text { experiment }\end{array}$ & $\begin{array}{l}\text { Reading } \\
\text { books } \\
\text { about } \\
\text { science }\end{array}$ & $\begin{array}{l}\text { Memorizin } \\
\text { g science } \\
\text { facts }\end{array}$ & $\begin{array}{l}\text { Write or } \\
\text { give an } \\
\text { explanation }\end{array}$ & $\begin{array}{l}\text { Work out } \\
\text { science } \\
\text { problems on } \\
\text { my own }\end{array}$ \\
\hline $\begin{array}{c}\mathrm{C} 1 \\
(\text { High SES) }\end{array}$ & 64.26 & 94.49 & 71.14 & 97.73 & 107.00 & 68.80 & 56.09 & 65.30 & 59.87 \\
\hline $\begin{array}{c}\mathrm{C} 2 \\
(\text { Med SES) }\end{array}$ & 75.61 & 64.78 & 67.18 & 59.57 & 58.89 & 69.86 & 76.50 & 72.32 & 80.48 \\
\hline $\begin{array}{c}\text { C3 } \\
\text { (Low SES) }\end{array}$ & 71.74 & 53.46 & 72.83 & 55.07 & 47.14 & 72.62 & 78.48 & 73.68 & 71.50 \\
\hline Asymp. Sig. & .361 & $.000 *$ & .775 & $.000 *$ & $.000^{*}$ & .878 & $.005^{*}$ & .430 & $.032 *$ \\
\hline $\begin{array}{c}\text { A1 } \\
\text { (High SES) }\end{array}$ & 47.34 & 49.58 & 72.42 & 65.55 & 57.81 & 57.98 & 56.89 & 59.55 & 50.37 \\
\hline $\begin{array}{c}\text { A2 } \\
\text { (Med SES) }\end{array}$ & 56.85 & 50.26 & 51.50 & 50.85 & 49.53 & 54.37 & 51.72 & 61.26 & 57.96 \\
\hline $\begin{array}{c}\text { A3 } \\
\text { (Low SES) }\end{array}$ & 54.11 & 57.98 & 39.23 & 45.10 & 52.23 & 47.98 & 51.08 & 40.90 & 50.83 \\
\hline Asymp. Sig. & .381 & .376 & $.000 *$ & $.010^{*}$ & .481 & .332 & .675 & $.003 *$ & .475 \\
\hline
\end{tabular}


Table 7. Further Mann-Whitney U Test of students' perceived frequency of classroom learning activities

\begin{tabular}{cccccccc}
\hline \multicolumn{7}{c}{ Statistical differences of students' perceived frequency of learning activities } \\
(Asymp. Sig. 2-tailed)
\end{tabular}




\section{Appendix A}

\section{Teacher Interview Protocol}

1. What is the highest level of formal education you have completed?

2. Do you have a specialization in science?

3. How many years have you been teaching/teaching science?

4. How many teaching hours are you allocated to science per week?

5. Is the decision at the school-level, state/provincial level or national level?

6. Do you use textbooks in your science lessons?

7. If yes, may I have a look at the textbook?

8. How do you use it? Do you use it as a primary basis for teaching or a supplementary resource?

9. If not, what materials do you use for guiding science teaching? Where do you get the materials and how do you prepare them for each student?

10. Where do you get materials for conducting experiments or investigations?

11. Do you have difficulty getting these materials?

12. Does your school have a science laboratory with equipment and materials? 


\section{Appendix B}

\section{Lesson Observation Protocol}

Sequence of lesson.

Each lesson is divided into three segments:

1. lesson introduction,

2. student activity in body of lesson,

3. lesson conclusion

The nature of the learning environment, including

1. the number of students in the class

2. whether they work in groups or individually

3. the way that the desks are arranged

The methods teachers use for engaging students in work.

1. how the teacher structures lessons, lesson aims, learning tasks,

2. how the teacher sets up for seatwork

3. the teacher's role during the lesson/group work

4. the use of instructional materials

5. the use of the chalkboard/whitboard/ICT

6. the use of manipulatives/science equipment 


\section{Appendix C}

\section{Student Questionnaire}

\section{What is your first name?}

2 What is your last name?

3 What is your date of birth?

Day

Month

Year

4 Are you a girl or a boy? Fill in one circle only

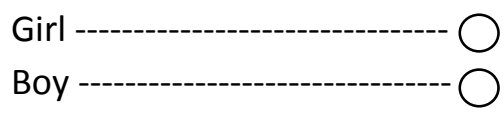

5 In school, how often do you do these things?

Fill in one circle for each line

a) I look at something like the

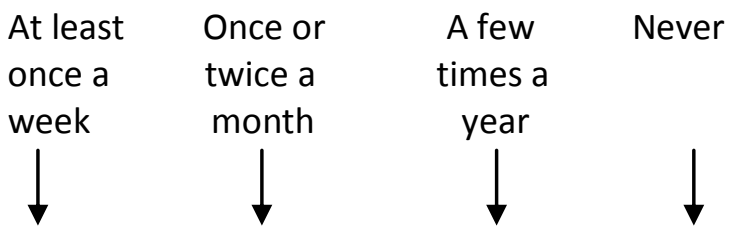

weather or a plant growing and write down what I see-
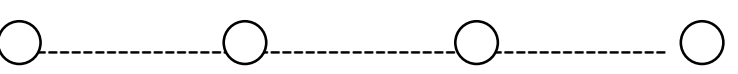

b) I watch the teacher do a science experiment-

c) I design or plan a science experiment or investigation-

d) I do a science experiment or investigation-

e) I work with other students in a small group on a science experiment or investigation

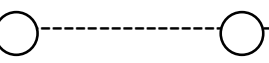

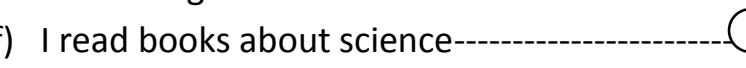

g) I memorise science facts

h) I write or give an explanation for something I am studying in science

i) I work science problems on my own<smiles>O</smiles><smiles>O</smiles> 
j) I use a computer in science lessons

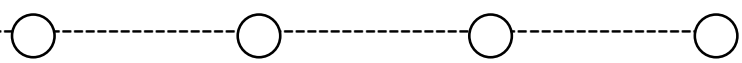

\section{1 请问你叫什么名字?}

2 请问你的出生日期?

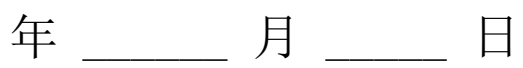

3 你是女生还是男生? 请填涂一个

女生

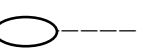

男生

\section{4. 在学校上科学课时, 你常做下面的事吗?}

\section{每小题请填涂一项}

$\begin{array}{llll}\text { 每周至少 } & \text { 每月 } & \text { 每年 } & \text { 从来 } \\ \text { 一次 } & 1-2 \text { 次 } & \text { 几次 } & \text { 没有 }\end{array}$

1) 我观察如天气或植物生长等现象,

并做记录-

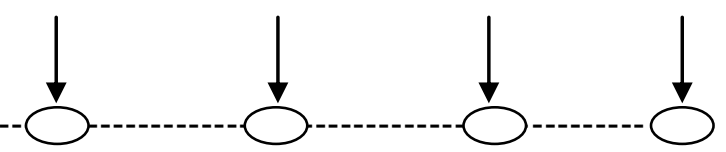

2) 我看老师做科学实验

3) 我自己设计一个科学实验或研究

4) 我做科学实验或研究

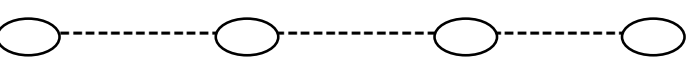

5) 我和同学分组一起做科学实验或研究----- $\bigcirc$

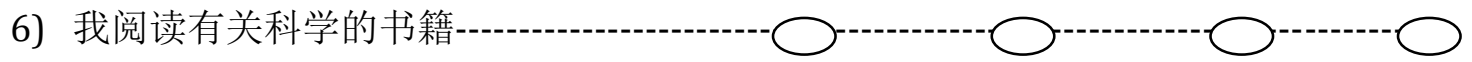

7) 我记忆科学知识-

8) 我通过写或说来进一步理解

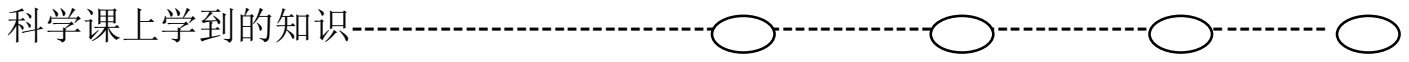

9) 我独立完成科学题目
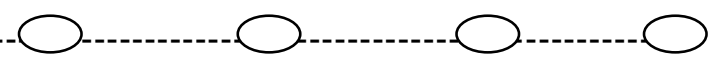

我在科学课堂上使用电脑 